\title{
Nutrients, fatty acid composition and antioxidant activity of the flowers and seed oils in wild populations of Paeonia Iudlowii
}

\author{
Jie Li, Zai-Hua Wang* \\ Guangdong Provincial Key Lab of Ornamental Plant Germplasm Innovation and Utilization, Environmental Horticulture Research Institute, \\ Guangdong Academy of Agricultural Sciences, Guangzhou, China
}

\section{A B S T R A C T}

\begin{abstract}
Wild Paeonia ludlowii is considered as a traditional ornamental plant, but its flowers and seed oils are edible with important economic values, and the variation of nutrients, fatty acid composition in wild populations is scarcely known. Flowers and seeds of $P$. ludlowii were collected from two wild populations for evaluating the nutrients in flowers, composition of fatty acids in seed oils and the antioxidant activity. The flowers contained high composition of proteins, carbohydrates, amino acids, total flavonoids, phenolic compounds and essential minerals. Seed oil yield reached up to $21.95 \%$ using supercritical $\mathrm{CO}_{2}$ fluid extraction, and it contained 14 fatty acids (up to $93.35 \mathrm{~g} / 100 \mathrm{~g}$ seed oil), especially the unsaturated fatty acids (oleic acid, linoleic acid and $\alpha$-linolenic acid) was up to $88.69 \%$ with low $\omega 6 / \omega 3$ ratios of 0.58 . The antioxidant capacity can be arranged in the order of trolox $>$ flower extracts $>$ seed oil according to the DPPH and ABTS free radical assay. Contents of nutrient in flowers and fatty acids in seed oils were significantly different between two wild populations due to the impact of different growing environments. These results indicate that flowers and seed oils of $P$. ludlowii are potential food resources in human diets.
\end{abstract}

Keywords: Paeonia ludlowii; Flowers; Nutrients; Seed oil; Antioxidant activity

\section{INTRODUCTION}

Paeonia, the only genus in the family Paeoniaceae, includes approximately 35 species that are divided into three sections (Moutan, Oneapia, and Paeonia) (He et al., 2014). Paeonia ludlowii belongs to the section Moutan (named tree peony), and it is one of wild species, and mainly distributed in sparse forests, woods and thickets of southeastern Tibet (Zhou, 2006). Because of the diverse growing environments, there are abundant genetic diversity among different wild populations (Tang et al., 2012).

Paeonia ludlowiiis well known for its ornamental value due to the big and yellow flowers, and its morphological characters are distinctly different from the other species in section Moutan (Hong, 1997), and it has become an ornamental flower with local characteristics. Meanwhile, the flowers of Paeonia species are edible, and many of them are widely used as delicacies for refreshments (Shi et al., 2006). Edible flowers usually play an important role in human nutrition due to various nutrients, such as amino acids, proteins, mineral elements and antioxidants (Mlcek and Rop, 2011), but there is no information concerning the nutritional components of $P$. ludlowii flowers.

Paeonia ludlowii is also a medicinal plant, the roots contain paeonol which is a Chinese herbal medicine, and widely used in East Asia to treat female genital and cardiovascular diseases (Picerno et al., 2011). He et al. (2014) also analyzed the root cortex metabolic fingerprinting of tree peonies, and found that metabolic profiles of P. ludlowii had significant differences compared with other six species. Recently, Zhang et al. (2017a) found the seeds of tree peony were rich in phenolic compounds, which can be used as useful sources of natural antioxidants. Seed oil of tree peony has also attracted considerable attention, researchers reported that the seeds of some wild tree peony species were characterized by abundant unsaturated fatty acids (FA), such

\footnotetext{
*Corresponding author:

Zai-Hua Wang, Guangdong Provincial Key Lab of Ornamental Plant Germplasm Innovation and Utilization, Environmental Horticulture Research Institute, Guangdong Academy of Agricultural Sciences, Guangzhou, China. E-mail: wang211210@163.com
} 
as $\alpha$-linolenic acid, oleic acid, and linoleic acid (Yu et al., 2016; Zhang et al., 2017b). Li et al. (2015) also found six cultivars had high FA yield selected from 60 ornamental cultivars of tree peony. However, the diversity of FA content and composition remains unclear in $P$. Iudlowii seed oils from different wild populations and locations, and the potential antioxidant activity of seed oil has not been assessed.

The objectives of the present study were to evaluate the nutritional value of flowers, fatty acid composition of seed oils and their antioxidant activity in two wild populations of P. ludlowii. This work could be helpful for the potential development and utilization of $P$. Indlowii as a new resource food.

\section{MATERIAL AND METHODS}

\section{Plant materials}

The flowers and seeds of P. Iudlowii were collected from two different wild populations (Zhagonggou and Caimicun) in Tibet of China. More than 50 full-bloom flowers from different plants were harvested in each location in May 2016 , and immediately dried in an oven at $50^{\circ} \mathrm{C}$ for $48 \mathrm{~h}$, and then crushed into powders, and stored at $4^{\circ} \mathrm{C}$. Mature seeds were hand-picked in October of 2016, and dried in an oven at $50^{\circ} \mathrm{C}$ until constant weight, and weighed, husked and ground to fine powders, then immediately extracted for seed oil. The plants in Zhagonggou population grow at an altitude of $3210 \mathrm{~m}$ on the slopes with enough sunshine, while the plants in Caimicun population grow at an altitude of $2939 \mathrm{~m}$ along the Yarlung Zangbo River, and they were under the tall trees.

\section{Proximate composition of flowers}

The nutritional value of flowers was calculated based on proteins, carbohydrates, fat, moisture and ash. Protein content $(\mathrm{N} \times 6.25)$ was calculated as nitrogen content by the Kjeldahl method (AOAC, 2000). Fat, moisture and ash contents were also determined using standard AOAC methods (AOAC, 2000). The carbohydrate content was determined according to James (1996).

\section{Total phenolic content (TPC) and total flavonoid content (TFC)}

The flower extraction using methanol was performed according to the method elaborated by Amri et al. (2017). Then, the Folin-Ciocalteu assay was used to determine the TPC following the description of Ado et al. (2015). TPC was expressed as $\mathrm{g}$ of gallic acid equivalent per $100 \mathrm{~g}$ of dried weight (g GAE/100 g DW). TFC was determined according to the method of Amri et al. (2017), and TFC was expressed as $\mathrm{g}$ of rutin equivalent per $100 \mathrm{~g}$ of dried weight (g REQ/100 g DW).

\section{Content of mineral elements}

The dried flower samples were digested with $\mathrm{HNO}_{3}-\mathrm{HClO}_{4}$ (v/v, 4:1) to determine the $\mathrm{Ca}, \mathrm{Mg}, \mathrm{Zn}, \mathrm{Fe}, \mathrm{Cu}$ and $\mathrm{Mn}$ concentrations as the methods of Gui et al. (2014). Flower sample (0.2 g) was put into a polyethylene bottle with $20 \mathrm{~mL}$ $1 \mathrm{~mol} / \mathrm{L}$ of $\mathrm{HCl}$, shaken for $2 \mathrm{~h}$ at a rate of $180 \mathrm{rpm}$, and then filtered to determine the Boron (B) concentration (Gui et al., 2014). The nutrient concentration of the flower was expressed in dry weight.

\section{Amino acids analysis}

Determination of hydrolytic amino acids in flowers was carried out using an automatic amino acid analyzer (Sykam S-433D, German) with analytical column (PEEK, $4.6 \mathrm{~mm} \times 150 \mathrm{~mm}, 5 \mu \mathrm{m})$ according to the method of Zhang et al. (2014). Amino acid standards (Sigma-Aldrich) were used for identification and quantification. The amino acid composition was expressed as $\mathrm{mg} / \mathrm{g}$ of the dry flower weight.

\section{Seed oil extraction}

The fatty acids (FA) of seeds were extracted by the method of supercritical $\mathrm{CO}_{2}$ fluid extraction (SFE) using a HA12050-02 SFE device (Hua' an Supercritical Fluid Extraction Corp., Nan-tong, China). Samples (120 g) of seed powders were placed into the extraction vessel. The liquid $\mathrm{CO}_{2}$ was pumped into the extractor to soak the seed powders under $30 \mathrm{MPa}$ at $45^{\circ} \mathrm{C}$ for $2 \mathrm{~h}$, and the $\mathrm{CO}_{2}$ flow rate $25 \mathrm{~kg} / \mathrm{h}$. The amount of extracted oil was determined gravimetrically after collection, and the oil yield is expressed as the percent ratio of the mass of extracted oil to the mass of seed powders loaded in the extraction vessel.

\section{Fatty acid methylation and GC-MS analysis}

Fatty acids (FA) were transformed to their methyl esters (FAME) following the method of Wang et al. (2015). The FAME samples were analyzed by a gas chromatograph mass spectrometer (GC7890A-5975C, Agilent) equipped with a 7683 autosampler tray module and a 7683 autoinjector module (Agilent). The column was VF-WAXms $(30 \mathrm{~m} \times 0.25 \mathrm{~mm}$, $0.25 \mu \mathrm{m}$ film thickness, Agilent). Operating conditions of GC-MS were as follows: $80^{\circ} \mathrm{C}$ for $2.5 \mathrm{~min}, 80-210^{\circ} \mathrm{C}$ at $15^{\circ} \mathrm{C} /$ min, $210-230^{\circ} \mathrm{C}$ at $2^{\circ} \mathrm{C} / \mathrm{min}$, and held at $230^{\circ} \mathrm{C}$ for $10 \mathrm{~min}$. The carrier gas was He at a flow rate of $1.0 \mathrm{~mL} / \mathrm{min}$, and the injection port was set at $250^{\circ} \mathrm{C}$ for split injection at a split ratio of 20:1. The inject volume was $1 \mu \mathrm{L}$. The ionization potential of the mass-selective detector was $70 \mathrm{eV}$ and the scanning range was 40-460 amu. Analyses were performed in four times $(n=4)$. The peaks of FAME were identified by comparing the mass spectra database (NIST2011 Library), and authentic standards.

\section{Qualitation and quantification of FA}

Fatty acid methyl esters (FAME) were initially identified through a mass spectra database search. To avoid the 
confusion of isomers, the five major compounds (palmitic acid methyl ester, stearic acid methyl ester, methyl oleate, linoleic acid methyl ester and linolenic acid methyl ester) were achieved by reference to corresponding authentic standards (Sigma). Other nine minor components were confirmed by comparing retention time and MS spectra with the 37-component FAME Mix ( $\mathrm{C}_{4}-\mathrm{C}_{24}$ unsaturates). The five major FAME in each sample were quantified in absolute terms by linear regression of their corresponding standards, while the nine minor FAME were measured using methyl tridecanoate (Sigma) as the internal standard. The content of each FAME was transferred to the corresponding FA content, and they were expressed as gram per 100 grams seed oil. All samples were analyzed in four times.

\section{Assay of DPPH radical-scavenging activity}

Flower powders ( $2 \mathrm{~g}$ ) were soaked in $100 \mathrm{~mL} \mathrm{50 \%} \mathrm{ethanol}$ and extracted in $60^{\circ}$ Cwater bath for $1 \mathrm{~h}$, the solution was cooled, weighed and replenished the lost weigh with 50\% ethanol. After filtering, the flower extract was obtained. The concentration of flower extract was $20 \mathrm{mg}$ flower powder in $1 \mathrm{~mL} \mathrm{50 \%} \mathrm{ethanol,} \mathrm{and} \mathrm{then} \mathrm{it} \mathrm{was} \mathrm{diluted} \mathrm{into}$ $0.03,0.06,0.125,0.25,0.50,1.00 \mathrm{mg} / \mathrm{mL}$ for antioxidant activity test. The seed oil was also diluted into 5, 10, 20, 30,40 and $60 \mathrm{mg} / \mathrm{mL}$ with ethanol for antioxidant activity test. The DPPH radical scavenging activity of samples were evaluated by the method of Li et al. (2011). A volume of $2 \mathrm{~mL}$ of each sample was incubated with $2 \mathrm{~mL}$ of DPPH solution $\left(0.2 \mathrm{mM}\right.$ in ethanol) at $25{ }^{\circ} \mathrm{C}$ for $30 \mathrm{~min}$ in the dark, and the absorbance of the mixture was measured at $517 \mathrm{~nm}$. Trolox (Sigma-Aldrich) was used as the control.
The 50\% inhibitory concentration $\left(\mathrm{IC}_{50}\right)$ was calculated using linear regression.

\section{Assay of ABTS radical-scavenging activity}

The ABTS free radical scavenging test was modified according to the method of Re et al. (1999). The ABTS diammonium salt $(10 \mathrm{mg})$ was added to $2.6 \mathrm{~mL} 2.45 \mathrm{mM}$ potassium persulfate, and this mixture was allowed to stand for 12-16 h at room temperature in the dark to create a dark blue-green radical solution. The solution was then diluted with anhydrous ethanol to an absorbance of $0.700 \pm 0.001$ at $734 \mathrm{~nm}$ to form the test reagent. A volume of $1 \mathrm{~mL}$ sample or Trolox was incubated with $3 \mathrm{~mL}$ test reagent at $25^{\circ} \mathrm{C}$ for $30 \mathrm{~min}$ in dark, and the absorbance was recorded at $734 \mathrm{~nm}$, and $\mathrm{IC}_{50}$ was also calculated.

\section{Statistical analysis}

Analysis of variance (ANOVA) and Student's t-test were used to evaluate differences between two locations, all analyses were performed on the SAS software (version 8.0) and considered significant when $p<0.05$.

\section{RESULTS AND DISCUSSION}

\section{Chemical composition of flowers}

Proximate analysis was conducted to examine the chemical composition and nutritional value of the flowers. The flowers of $P$. Indlowii contained high composition of ash, carbohydrates and protein (Table 1). The high ash content was indicative of the presence of large amounts of minerals. The ash content $(5.1-5.6 \mathrm{~g} / 100 \mathrm{~g})$ was found to be higher than that of chestnut flowers (Carocho et al.,

Table 1: Proximate composition, effective components and mineral elements of Paeonia ludlowii flowers in two locations

\begin{tabular}{|c|c|c|c|c|}
\hline & Components & Caimicun & Zhagonggou & Mean \\
\hline \multirow[t]{6}{*}{ Proximate composition (\%) } & Moisture & $9.9 \pm 0.3^{a}$ & $10.0 \pm 0.2^{\mathrm{a}}$ & 9.95 \\
\hline & Ash & $5.1 \pm 0.3^{\mathrm{a}}$ & $5.6 \pm 0.3^{a}$ & 5.35 \\
\hline & Proteins & $15.7 \pm 0.4^{b}$ & $18.4 \pm 0.5^{\mathrm{a}}$ & 17.05 \\
\hline & Lipids & $3.4 \pm 0.2^{\mathrm{a}}$ & $2.4 \pm 0.3^{b}$ & 2.90 \\
\hline & Carbohydrates & $65.8 \pm 2.1^{\mathrm{a}}$ & $63.6 \pm 1.7^{a}$ & 64.70 \\
\hline & Energy ${ }^{b}$ & $356.6 \pm 3.1^{\mathrm{a}}$ & $349.6 \pm 2.3^{b}$ & 353.10 \\
\hline \multirow[t]{2}{*}{ Effective components (\%) } & TFC & $1.58 \pm 0.02^{\mathrm{a}}$ & $1.38 \pm 0.02^{b}$ & 1.48 \\
\hline & TPC & $8.92 \pm 0.14^{a}$ & $8.75 \pm 0.16^{a}$ & 8.84 \\
\hline \multirow[t]{8}{*}{ Mineral elements ${ }^{c}$} & $\mathrm{~K}$ & $1.67 \pm 0.00^{b}$ & $1.71 \pm 0.01^{\mathrm{a}}$ & 1.69 \\
\hline & $\mathrm{Ca}$ & $0.32 \pm 0.00^{b}$ & $0.45 \pm 0.00^{\mathrm{a}}$ & 0.39 \\
\hline & $\mathrm{Mg}$ & $0.19 \pm 0.00^{b}$ & $0.24 \pm 0.00^{\mathrm{a}}$ & 0.22 \\
\hline & $\mathrm{Mn}$ & $10.95 \pm 0.07^{b}$ & $16.35 \pm 0.07^{a}$ & 13.65 \\
\hline & $\mathrm{Zn}$ & $32.50 \pm 0.71^{b}$ & $37.00 \pm 0.00^{\mathrm{a}}$ & 34.75 \\
\hline & $\mathrm{Fe}$ & $68.65 \pm 0.35^{a}$ & $66.55 \pm 1.91^{\mathrm{a}}$ & 67.60 \\
\hline & $\mathrm{Cu}$ & $9.95 \pm 0.07^{a}$ & $9.45 \pm 0.21^{b}$ & 9.70 \\
\hline & B & $14.65 \pm 0.21^{\mathrm{a}}$ & $14.15 \pm 0.49^{a}$ & 14.40 \\
\hline
\end{tabular}

aProximate composition and effective components are expressed as g per $100 \mathrm{~g}$ on dry weight, except energy which is expressed in kcal per $100 \mathrm{~g}$ on dry weight, ${ }^{b}$ Energy was calculated using $4 \mathrm{kcal} / \mathrm{g}$ for proteins and carbohydrates and $9 \mathrm{kcal} / \mathrm{g}$ for lipids, ${ }^{\mathrm{C}} \mathrm{K}, \mathrm{Ca}$ and $\mathrm{Mg}$ are expressed as percentage of dry flower and for $\mathrm{Mn}, \mathrm{Zn}, \mathrm{Fe}, \mathrm{Cu}$ and $\mathrm{B}$ as $\mathrm{mg} / \mathrm{kg}$ of dry flower. TFC and TPC represents the content of total flavonoids and total polyphenols. All data was Mean \pm SD, different letters with in a line indicate significant statistical differences $(p<0.05)$. 
2015). The protein content (15.7-18.4 g/100 g) was higher than that of Crocus sativus flowers $(10.1 \mathrm{~g} / 100 \mathrm{~g}$ ) (SerranoDíaz et al., 2013). The energy contribution of $100 \mathrm{~g}$ of whole flowers was low, ranging from 349.6 to $356.6 \mathrm{kcal}$, the consumption of $100 \mathrm{~g}$ of these flowers would provide an energy intake from $17.4 \%$ to $17.8 \%$ in a standard daily diet of $2000 \mathrm{kcal}$.

\section{Total flavonoid content (TFC) and total phenolic content (TPC)}

Increased consumption of flavonoids and phenolic compounds has been correlated with antioxidant and anti-inflammatory activities, and a reduced risk of cardiovascular disease and certain cancers (Mlcek and Rop, 2011; Chen et al., 2015). The results presented the differences of TFC and TPC extracted from dry flowers of $P$. Indlowii (Table 1), the accumulated quantities of TFC in Caimicun was significantly higher than that in Zhagonggou, but the TPC was insignificant. Compared with the other Paeonia species, the level of TFC found in P. Indlowii flowers was lower than that in four tree peony cultivars reported by Shi et al. (2006), whereas the content of phenolic compounds was higher here than that reported by the same authors. Meanwhile, Zheng et al. (2015) found that both of TFC and TPC increased firstly and then decreased during blooming, with the highest at full-bloom stage. In this study, $P$. Indlowii flowers were collected at full-bloom stage, its TFC in dry flowers was similar with loquat flowers, but the TPC in P. ludlowii flowers was nearly two times than that in loquat flowers.

\section{Mineral elements content}

Table 1 also shows the results regarding some nutritionally important minerals. The main difference of flowers was detected in the level of $\mathrm{K}, \mathrm{Ca}, \mathrm{Mg}$ and the minor nutritional elements $(\mathrm{Mn}, \mathrm{Zn}$ and $\mathrm{Cu}$ ). In Zhagonggou, flowers exhibited much higher levels of $\mathrm{K}, \mathrm{Ca}, \mathrm{Mg}, \mathrm{Mn}$ and $\mathrm{Zn}$, and the contents of $\mathrm{Fe}$ and $\mathrm{B}$ were insignificant between two locations. The content of $\mathrm{K}, \mathrm{Ca}$ and $\mathrm{Mg}$ in this work were higher than Crocus sativus flowers (Serrano-Díaz et al., 2013), and similar with Rosa laxa pollen, while the content of Fe, $\mathrm{Zn}$ and $\mathrm{Cu}$ of P. Indlowii flower were higher than that in Rosa laxa pollen and hip described by Li et al. (1997), and $\mathrm{Fe}, \mathrm{Zn}$ content was also similar with pear flowers (Ammar et al., 2014).

\section{Amino acid composition}

The amino acid composition of $P$. Indlowii flowers indicated the presence of 17 amino acids (Table 2). The content of total essential amino acids (EAA) in Zhagonggou and Caimicun were $45.03 \mathrm{mg} / \mathrm{g}$ and $39.41 \mathrm{mg} / \mathrm{g}$ in dry flower weight, respectively, and accounted for $34.91 \%$ and $35.85 \%$ of the total amino acid content, which is slightly lower than the reference value of $40 \%$ recommended by FAO/WHO (Pellett and Young, 1980). In addition, the ratio of EAA to non-essential amino acid (NAA) for Zhagonggou and Caimicun were $53.64 \%$ and $55.89 \%$, which is slightly lower than the reference protein pattern of $60 \%$ recommended by FAO/WHO. It could be seen that glutamic (Glu) and aspartic acids (Asp) had the highest concentrations in two locations, while methionine (Met) and cysteine (Cys) recorded relatively lower. Both of the total contents of EAA and NAA in Zhagonggou were significantly higher than that in Caimicun. Similar results were found in the fruits of Schinus terebinthifolius and Schinus mole when they were collected from two locations in Tunisia (Tlili et al., 2018), and the possible reasons were the differences of climatic conditions and soil of an area.

\section{Composition and content of fatty acids (FA)}

The seeds of $P$. Indlowii were collected from two wild populations (Zhagonggou and Caimicun). The mean dry weight per 100 seeds in Zhagonggou was $85.42 \pm 1.63 \mathrm{~g}$, while Caimicun seeds was $83.19 \pm 1.55 \mathrm{~g}$. The seed oil yield was $20.75-21.95 \%$, according to the ratio of seed oil weight to dry seed weight.

The FA characterization of seed oil is shown in Fig 1. A total of $14 \mathrm{FA}$ were found with $80.66-93.35 \mathrm{~g}$ in $100 \mathrm{~g}$

Table 2: Amino acid compositions of Paeonia ludlowii flowers in two locations ( $\mathrm{mg} / \mathrm{g}$ of dry flower weight)

\begin{tabular}{lccc}
\hline Essential amino & Caimicun & Zhagonggou & Mean \\
\hline lle & & & \\
Met & $5.20 \pm 0.01^{\mathrm{a}}$ & $5.70 \pm 0.07^{\mathrm{a}}$ & 5.45 \\
Val & $0.31 \pm 0.01^{\mathrm{a}}$ & $0.33 \pm 0.01^{\mathrm{a}}$ & 0.32 \\
Phe & $6.40 \pm 0.00^{\mathrm{b}}$ & $7.10 \pm 0.01^{\mathrm{a}}$ & 6.75 \\
Thr & $4.90 \pm 0.00^{\mathrm{b}}$ & $5.60 \pm 0.07^{\mathrm{a}}$ & 5.25 \\
Leu & $4.90 \pm 0.02^{\mathrm{b}}$ & $5.50 \pm 0.07^{\mathrm{a}}$ & 5.20 \\
Lys & $8.40 \pm 0.00^{\mathrm{b}}$ & $9.35 \pm 0.11^{\mathrm{a}}$ & 8.88 \\
His & $6.50 \pm 0.02^{\mathrm{b}}$ & $8.30 \pm 0.01^{\mathrm{a}}$ & 7.40 \\
Total & $2.80 \pm 0.00^{\mathrm{b}}$ & $3.15 \pm 0.01^{\mathrm{a}}$ & 2.98 \\
\hline Non-essential amino & $39.41 \pm 0.02$ & $45.03 \pm 1.00$ & 42.22 \\
acid (NAA) & & & \\
\hline Asp & & & \\
Ser & $12.10 \pm 0.01^{\mathrm{b}}$ & $15.60 \pm 0.14^{\mathrm{a}}$ & 13.85 \\
Glu & $5.95 \pm 0.07^{\mathrm{b}}$ & $6.75 \pm 0.04^{\mathrm{a}}$ & 6.35 \\
Pro & $20.05 \pm 0.07^{\mathrm{b}}$ & $23.20 \pm 0.28^{\mathrm{a}}$ & 21.63 \\
Gly & $6.20 \pm 0.00^{\mathrm{b}}$ & $7.05 \pm 0.11^{\mathrm{a}}$ & 6.63 \\
Ala & $5.50 \pm 0.00^{\mathrm{b}}$ & $6.15 \pm 0.04^{\mathrm{a}}$ & 5.83 \\
Cys & $9.50 \pm 0.00^{\mathrm{b}}$ & $10.45 \pm 0.11^{\mathrm{a}}$ & 9.98 \\
Tyr & $0.71 \pm 0.01^{\mathrm{b}}$ & $0.85 \pm 0.00^{\mathrm{a}}$ & 0.78 \\
Arg & $3.10 \pm 0.00^{\mathrm{b}}$ & $3.50 \pm 0.07^{\mathrm{a}}$ & 3.30 \\
Total & $7.40 \pm 0.00^{\mathrm{b}}$ & $10.40 \pm 0.07^{\mathrm{a}}$ & 8.90 \\
EAA/(EAA+NAA) & $70.51 \pm 0.16$ & $83.95 \pm 1.70$ & 77.23 \\
EAA/NAA & $35.85 \%$ & $34.91 \%$ & $35.38 \%$ \\
\hline All da was Man & $55.89 \%$ & $53.64 \%$ & $54.77 \%$ \\
\hline
\end{tabular}

All data was Mean $\pm S D$, different letters within a line indicate significant statistical differences $(p<0.05)$. 
seed oil (Table 3). Palmitic acid (C16:0, peak 3), stearic acid (C18:0, peak 7), oleic acid (C18:1 ${ }^{\Delta 9}$, peak 8), linoleic acid $\left(\mathrm{C} 18: 2^{\Delta 9,12}\right.$, peak 9) and $\alpha$-linolenic acid (C18:3 $3^{\Delta 9,12,15}$, peak 11) were the five dominant $F A$, together comprising $96.6 \%$ - $97.8 \%$ of total FA, respectively. Especially, the oleic acid content was the highest, and reached $32.83-37.74 \mathrm{~g}$ per $100 \mathrm{~g}$ oil, and followed with $\alpha$-linolenic acid (23.40 $26.49 \mathrm{~g}$ per $100 \mathrm{~g}$ oil), which was line with the results of 11 species of Paeonia and 60 ornamental cultivars of tree peony (Yu et al., 2016; Li et al., 2015). Nine other minor FA were also found in $P$. Indlowii seed oil, but their contents of every $100 \mathrm{~g}$ oil were below $0.5 \mathrm{~g}$, this was different with the report that only four minor FA were found in the seeds of 60 tree peony cultivars ( $\mathrm{Li}$ et al., 2015), and Zhang et al. (2018) found ten minor FA in the seed oil of four Paeonia species ( $P$. ostii, $P$. rockii, $P$. veitchii and $P$. lactiflora). These results indicated that the seeds of different Paeonia species contained diverse minor FA except the five main FA. In addition, the content of unsaturated FA (UFA) varied from $88.05 \%-88.69 \%$ in seed oil, which was higher than that of Canola, Sunflower and Cardoon (Carvalho et al., 2006).

The composition and content of FA was often affected by environmental factors, especially temperature. Angeloni et al. (2017) indicated that oleic acid percentage in sunflower oil was closely related to minimum night temperature during a short period of grain filling. Rondanini et al. (2014) found that temperature during oil synthesis was negatively related to final oil concentration of olive. Tlili et al. (2018) found that temperature can affect fatty acid composition of Schinus terebinthifolius and Schinus molle fruits, particularly palmitic, oleic and linoleic acids. In this study, location explained an important proportion of variability of seed oil when comparing $P$. Indlowii from fairly high

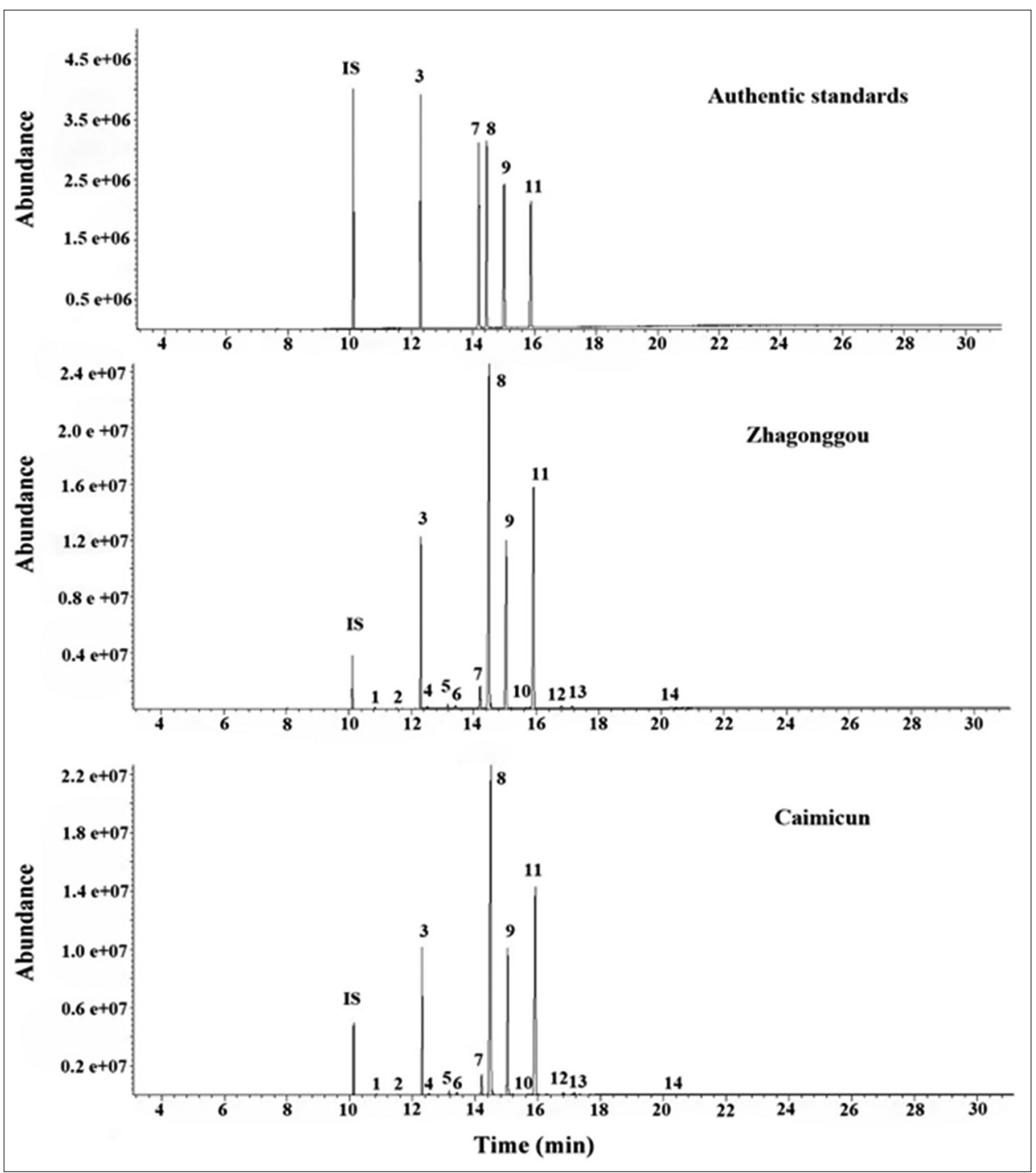

Fig 1. GC-MS of fatty acids in the seed oils of Paeonia ludlowii from two locations. Peaks: IS = C13:0 (internal standard). $1=$

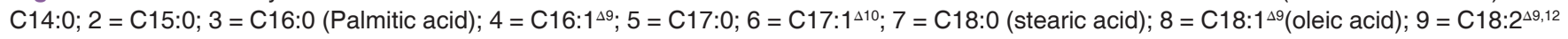

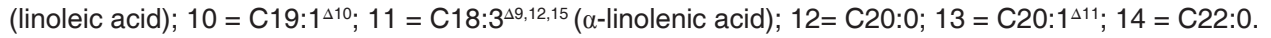


mountainside (Zhagonggou, $3210 \mathrm{~m}$ asl) with a lower elevation river valley (Caimicun, $2939 \mathrm{~m}$ asl), the higher content of FA, especially unsaturated FA, may be related to the lower temperature in Zhagonggou. Moreover, plants of $P$. ludlowii grew under the tall trees in Caimicun, the low FA content of them could be also relative to insufficient light, which was in agreement with the results of Han et al. (2018), who indicated that light shading could improve seed weight and content of unsaturated FA in seed oil of P. ostii 'Feng Dan', while moderate or severe shading was opposite.

The $\omega 6$ and $\omega 3$ FA are commonly in the form of linoleic acid and $\alpha$-linolenic acid, and they have reciprocal biological activities. Table 3 also showed that the ratios of $\omega 6 / \omega 3 \mathrm{FA}$ ranged from 0.58 to 0.65 in two locations, which agreed with the report that $\omega 6 / \omega 3$ ratio in peony seed oil was less than 1.0 in all observed species (Yu et al., 2016), and this ratio was also significantly lower than the seed oils of some crops (with the $\omega 6 / \omega 3$ ratio of 1.8-78.6) (Carvalho et al., 2006). High $\omega 6 / \omega 3$ ratio usually could promote the pathogenesis of many diseases, including cardiovascular disease, cancer, inflammatory and autoimmune diseases, whereas increased levels of $\omega 3$ UFA (a low $\omega 6 / \omega 3$ ratio) exert suppressive effects (Simopoulos, 2002).

\section{Antioxidant activities}

A dose-dependent capacity for radical scavenging activity of DPPH and ABTS radicals were examined for oil and flower samples, and the $\mathrm{IC}_{50}$ values were calculated and listed in Table 4 . The antioxidant capacity can be arranged in the order, trolox $>$ flower extracts $>$ seed oil. The high antioxidant activity of flowers could be due to the bioactive component of flavonoids and phenolic compounds, which was also demonstrated in sunflower and 23 species of cultivated edible flowers (Ye et al., 2015; Chen et al., 2015). In addition, the DPPH and ABTS scavenging rate of seed oil reached above $90 \%$, which was higher than olive, sunflower, soybean and cotton seed oils (28.4-78.9\% radicals reduction) reported by Kalantzakis et al. (2006). However, there was no significant difference in seed oil and flower extract between two locations according to the $\mathrm{IC}_{50}$ values.

Table 3: Fatty acid content of Paeonia ludlowii seed oil in two locations

\begin{tabular}{|c|c|c|c|c|}
\hline \multirow[t]{2}{*}{ Fatty acids } & \multirow[t]{2}{*}{ Retention time (min) } & \multicolumn{2}{|c|}{ Content (g/100 g seed oil) } & \multirow[t]{2}{*}{ Mean } \\
\hline & & Caimicun & Zhagonggou & \\
\hline C16:0 & 12.308 & $6.87 \pm 0.17^{b}$ & $8.79 \pm 0.29^{a}$ & 7.83 \\
\hline C18:0 & 14.202 & $1.27 \pm 0.04^{b}$ & $1.53 \pm 0.06^{\mathrm{a}}$ & 1.40 \\
\hline $\mathrm{C} 18: 1^{\triangle 9}$ & 14.489 & $32.83 \pm 0.85^{b}$ & $37.74 \pm 1.13^{a}$ & 35.29 \\
\hline $\mathrm{C} 18: 2^{\triangle 9,12}$ & 15.039 & $13.54 \pm 0.42^{b}$ & $17.26 \pm 0.59^{a}$ & 15.40 \\
\hline C18:3 $3^{\Delta 9,12,15}$ & 15.916 & $23.40 \pm 0.74^{b}$ & $26.49 \pm 0.82^{a}$ & 24.95 \\
\hline C14:0 & 10.842 & $0.07 \pm 0.01^{b}$ & $0.09 \pm 0.004^{a}$ & 0.08 \\
\hline C15:0 & 11.544 & $0.04 \pm 0.01^{a}$ & $0.05 \pm 0.01^{a}$ & 0.05 \\
\hline $\mathrm{C} 16: 1^{\Delta 9}$ & 12.537 & $0.14 \pm 0.02^{b}$ & $0.18 \pm 0.01^{a}$ & 0.16 \\
\hline $\mathrm{C} 17: 0$ & 13.179 & $0.34 \pm 0.03^{b}$ & $0.42 \pm 0.02^{\mathrm{a}}$ & 0.38 \\
\hline$C 17: 1^{\Delta 10}$ & 13.413 & $0.28 \pm 0.04^{a}$ & $0.33 \pm 0.02^{\mathrm{a}}$ & 0.31 \\
\hline C19:1 $1^{\Delta 10}$ & 15.672 & $0.12 \pm 0.02^{\mathrm{a}}$ & $0.13 \pm 0.01^{a}$ & 0.13 \\
\hline $\mathrm{C} 20: 0$ & 16.821 & $0.28 \pm 0.04^{\mathrm{b}}$ & $0.37 \pm 0.02^{\mathrm{a}}$ & 0.33 \\
\hline $\mathrm{C} 20: 1^{\Delta 11}$ & 17.152 & $0.28 \pm 0.05^{a}$ & $0.33 \pm 0.03^{a}$ & 0.31 \\
\hline $\mathrm{C} 22: 0$ & 20.331 & $0.10 \pm 0.02^{\mathrm{a}}$ & $0.15 \pm 0.02^{\mathrm{a}}$ & 0.13 \\
\hline TFA amounts & & $80.66 \pm 1.37^{b}$ & $93.35 \pm 2.83^{a}$ & 87.01 \\
\hline SFA amounts & & $9.13 \pm 0.18^{b}$ & $11.15 \pm 0.33^{a}$ & 10.14 \\
\hline UFA amounts & & $71.53 \pm 1.20^{b}$ & $82.20 \pm 2.51^{a}$ & 76.87 \\
\hline$\%$ SFA of TFA & & 11.31 & 11.94 & 11.63 \\
\hline$\%$ UFA of TFA & & 88.69 & 88.05 & 88.37 \\
\hline$\omega 6 / \omega 3$ & & 0.58 & 0.65 & 0.62 \\
\hline
\end{tabular}

TFA: Total fatty acids; SFA: saturated fatty acids; UFA: unsaturated fatty acids. Values represent means \pm SD, and the different letters indicate significant difference at $P<0.05$ level.

Table 4: Comparison of antioxidant activity of seed oils and flower extracts

\begin{tabular}{|c|c|c|c|c|}
\hline \multirow[t]{2}{*}{ Samples } & \multicolumn{2}{|c|}{ Scavenging of DPPH, $I_{50},(\mathrm{mg} / \mathrm{mL})$} & \multicolumn{2}{|c|}{ Scavenging of $A B T S, I C_{50},(\mathrm{mg} / \mathrm{mL})$} \\
\hline & Seed oil & Flower extract & Seed oil & Flower extract \\
\hline Zhagonggou & $8.043 \pm 0.055^{b}$ & $0.031 \pm 0.000^{b}$ & $13.160 \pm 0.174^{b}$ & $0.334 \pm 0.024^{b}$ \\
\hline Caimicun & $8.079 \pm 0.041^{b}$ & $0.032 \pm 0.001^{\mathrm{b}}$ & $13.509 \pm 0.351^{b}$ & $0.346 \pm 0.008^{b}$ \\
\hline Trolox & $0.004 \pm 0.000^{\mathrm{a}}$ & $0.004 \pm 0.000^{\mathrm{a}}$ & $0.006 \pm 0.000^{\mathrm{a}}$ & $0.006 \pm 0.000^{\mathrm{a}}$ \\
\hline
\end{tabular}

The data are the means \pm SD $(n=3)$. Different letters in the same column indicate significant statistical differences $(p<0.05)$. 


\section{CONCLUSIONS}

The results presented in this study were the first data on the effect of location on the nutrition composition of flowers, seed oil and antioxidant activity of $P$. ludlowii. The results indicated that flowers of $P$. ludlowii contained lots of beneficial nutrients to the human body, and also exhibited a high antioxidant activity. Seed oil was rich in unsaturated FA, especially with high oleic acid, $\alpha$-linolenic acid and linoleic acid. It could be concluded that flowers and seed oils have the potential for healthy food in human diets. Content of nutrient in flowers and FA in seed oils were significantly different between two locations due to the impact of different growing environments, and detailed compounds of phenols and flavonoids in flowers will be studied in future work.

\section{ACKNOWLEDGEMENTS}

This work was supported by Guangdong Province Science and Technology Plan Project (No. 2016B020212006 and No. 2015A020210085).

\section{Authors' contributions}

Li J. designed research, performed research, analyzed data, and both of Li J. and Wang Z. H. wrote the paper.

\section{REFERENCES}

Ado, M. A., F. Abas, I. S. Ismail, H. M. Ghazali and K. Shaari. 2015. Chemical profile and antiacetylcholinesterase, antityrosinase, antioxidant and $\alpha$-glucosidase inhibitory activity of Cynometra cauliflora L. leaves. J. Sci. Food Agric. 95: 635-642.

Ammar, I., M. Ennouri, O. Bali and H. Attia. 2014. Characterization of two prickly pear species flowers growing in Tunisia at four flowering stages. LWT-Food Sci. Technol. 59: 448-454.

Amri, Z., F. Zaouay, H. Lazreg-Aref, H. Soltana, A. Mneri, M. Mars and M. Hammami. 2017. Phytochemical content, fatty acids composition and antioxidant potential of different pomegranate parts: comparison between edible and non edible varieties grown in Tunisia. Int. J. Biol. Macromol. 104: 274-280.

Angeloni, P., M. M. Echarte, G. P. Irujo, N. Izquierdo and L. Aguirrezabal. 2017. Fatty acid composition of high oleic sunflower hybrids in a changing environment. Field Crop Res. 202: 146-157.

AOAC. 2000. In W. Horwitz (Eds.), Official methods of analysis of the Association of Official Analytical Chemists. Washington DC, USA: AOAC.

Carocho, M., J. C. M. Barreira, L. Barros, A. Bento, M. Camara, P. Morales and I. C. F. R. Ferreira. 2015. Traditionalpastry with chestnut flowers as natural ingredients: An approach of the effects on nutritional value and chemical composition. J. Food Compos. Anal. 44: 93-101.

Carvalho, I. S., I. Miranda and H. Pereira. 2006. Evaluation of oil composition of some crops suitable for human nutrition. Ind. Crop and Prod. 24: 75-78.

Chen, G. L., S. G. Chen, Y. Q. Xie, F. Chen, Y. Y. Zhao, C. X. Luo and Y. Q. Gao. 2015. Total phenolic, flavonoid and antioxidant activity of 23 edible flowers subjected to in vitro digestion. $\mathrm{J}$. Funct. Foods. 17: 243-259.

Gui, H. P., Q. L. Tan, C. X. Hu, Y. Zhang, C. S. Zheng, X. C. Sun and X. H. Zhao. 2014. Floral analysis for Satsuma mandarin (Citrus unshiu Marc.) nutrient diagnosis based on the relationship between flowers and leaves. Sci. Hortic-Amsterd. 169: 51-56.

Han, C. J., Q. Wang, H. B. Zhang, S. H. Wang. H. D. Song, J. M. Hao and H. Z. Dong. 2018. Light shading improves the yield and quality of seed in oil-seed peony (Paeonia ostii Feng Dan). J. Integr. Agr. 17: 1631-1640.

He, C., B. Peng, Y. Dan, Y. Peng and P. Xiao. 2014. Chemical taxonomy of tree peony species from China based on root cortex metabolic fingerprinting. Phytochemistry, 107: 69-79.

Hong, D.Y. 1997. Paeonia (Paeoniaceae) in Xizang (Tibet). Novon. 7, 156-161.

James, C.S. 1996. Analytical chemistry of foods. Chapman \& Hall, New York.

Kalantzakis, G., G. Blekas, K. Pegklidou and D. Boskiu. 2006. Stability andradical-scavenging activity of heated olive oil and other vegetable oils. Eur. J. Lipid. Sci. Tech. 108: 329-335.

Mlcek, J. and O. Rop. 2011. Fresh edible flowers of ornamental plants - A new source of nutraceutical foods. Trends Food Sci. Tech. 22: 561-569.

Li, G. L., J. Y. Shi, Y. R. Suo, Z. W. Sun, L. Xia, J. Zheng, J. M. You and Y. J. Liu. 2011. Supercritical $\mathrm{CO}_{2}$ cell breaking extraction of Lycium barbarum seed oil and determination of its chemical composition by HPLC/APCI/MS and antioxidant activity. LWTFood Sci. Technol. 44: 1172-1178.

Li, Q. D., Y. Li and J. P. Liu. 1997. Yield and nutritional value of Rosa Zaxa Retz pollen. Sci. Hortic-Amsterd. 71: 43-48.

Li, S. S., R. Y. Yuan, L. G. Chen, L. S. Wang, X. H. Hao, L. J. Wang, X. C. Zheng and H. Du. 2015. Systematic qualitative and quantitative assessment of fatty acids in the seeds of 60 tree peony (Paeonia section Moutan DC.) cultivars by GC-MS. Food Chem. 173: 133-140.

Pellett, P. L. and V. R. Young. 1980. Nutritional evaluation of protein foods. Food Nutr. Bull. Suppl. 4: 167.

Picerno, P., T. Mencherini, F. Sansone, P. D. Gaudio, I. Granata, A. Porta and R. P. Aquino. 2011. Screening of a polar extract of Paeonia rockii: Composition and antioxidant and antifungal activities. J. Ethnopharmacol. 138: 705-712.

Re, R., N. Pellerrini, A. Proteggente, A. Pannala, M. Yang and C. Rice-Evansm. 1999. Antioxidant activity applying an improved ABTS radical cationdecolorization assay. Free Radical Bio. Med. 26: 1231-1237.

Rondanini, D. P., D. N. Castro, P. S. Searles and M. C. Rousseaux. 2014. Contrasting patterns of fatty acid composition and oil accumulation during fruit growth in several olive varieties and locations in a non-Mediterranean region. Europ. J. Agron. 52: $237-246$.

Serrano-Díaz, J., A. M. Sánchez, M. Martínez-Tomém, P. Winterhalter and G. L. Alonsol. 2013. A contribution to nutritional studies on Crocus sativus flowers and their value as food. J. Food Compos. Anal. 31:101-108.

Shi, G. A., X. F. Guo and M. Z. Bao. 2006. Analysis of nutritional components and antioxidant capacities in flowers of Peony. T. Chinese Soc. Agr. Machinery. 37: 111-114. (In Chinese).

Simopoulos, A. P. 2002. The importance of the ratio of omega-6/ omega-3 essential fatty acids. Biomed. Pharmacoth. 56: $365-379$.

Tang, Q., X. L. Zeng, M. A. Liao, C. T. Pan, X. Zha, J. H. Gong and Z. G. Ciren. 2012. SRAP analysis of genetic diversity of Paeonia 
Iudlowii in Tibet. Scientia Silvae Sinicae. 48: 70-76.

Tlili, N., Y. Yahia, A. Feriani, A. Labidi, L. Ghazouani, N. Nasri, E. Saasaoui and A. Khaldi. 2018. Schinus terebinthifolius vs Schinus molle: A comparative study of the effect of species and location on the phytochemical content of fruits. Ind. Crop Prod. 122: $559-565$.

Wang, C. Z., L. Xu, Q. Wu, H. K. Zhou, X. C. Ren and R. Yang. 2015. The importance of ultrahigh pressure processing over the quality of the extracted oil from peony seeds (Paeonia suffruticosa Andr.). Ind. Crop Prod. 76: 1142-1147.

Ye, F. Y., Q. Liang, H. Li and G. H. Zhao. 2015. Solvent effects on phenolic content, composition, and antioxidant activity of extracts from florets of sunflower (Helianthus annuus L.). Ind. Crop Prod. 76: 574-581.

Yu, S., S. Du, J. Yuan and Y. Hu. 2016. Fatty acid profile in the seeds and seed tissues of Paeonia L. species as new oil plant resources. Sci. Rep-UK. DOI: 10.1038/srep26944.

Zhang, H., Z. Y. Wang, X. Yang, H. T. Zhao, Y. C. Zhang, A. J. Dong and J. Wang. 2014. Determination of free amino acids and 18 elements in freeze-dried strawberry and blueberry fruit using an Amino Acid Analyzer and ICP-MS with micro-wave digestion.
Food. Chem. 147: 189-194.

Zhang, X. X., Q. Q. Shi, D. Ji, L. X. Niu and Y. L. Zhang. 2017a. Determination of the phenolic content, profile, and antioxidant activity of seeds from nine tree peony (Paeonia section-Moutan DC.) species native to China. Food Res. Int. 97: $141-148$.

Zhang, X. X., Y. L. Zhang, L. X. Niu, J. Y. Sun, L. H. Li, J. Zhang and J. Li. 2017b. Chemometric classification of different tree peony species native to China based on the assessment of major fatty acids of seed oil and phenotypic characteristics of the seeds. Chem. Biodiver.

Zhang, Y., P. Liu, J. Y. Gao, X. S. Wang, M. Yan, N. C. Xue, C. X. Qu and R. X. Deng. 2018. Paeonia veitchii seeds as a promising high potential by-product: Proximate composition, phytochemical components, bioactivity evaluation and potential applications. Ind. Crop Prod. 125: 248-260.

Zheng, M. Y., Q. L. Xia and S. M. Lu. 2015. Study on drying methods and their influences on effective components of loquat flower tea. LWT-Food Sci. Technol. 63: 14-20.

Zhou, Z. Q. 2006. Taxonomy, geographic distribution and ecological habitats of tree peonies. Genet. Resour. Crop Ev. 53: 11-22. 